Article

\title{
Investigating Students' Adoption of MOOCs during COVID-19 Pandemic: Students' Academic Self-Efficacy, Learning Engagement, and Learning Persistence
}

Mahdi Mohammed Alamri (D)

check for updates

Citation: Alamri, M.M. Investigating Students' Adoption of MOOCs during COVID-19 Pandemic: Students' Academic Self-Efficacy, Learning Engagement, and Learning Persistence. Sustainability 2022, 14 , 714. https://doi.org/10.3390/ su14020714

Academic Editors: Javier Cifuentes-Faura, Joseph Crawford and Jo-Anne Kelder

Received: 1 December 2021 Accepted: 23 December 2021 Published: 10 January 2022

Publisher's Note: MDPI stays neutral with regard to jurisdictional claims in published maps and institutional affiliations.

Copyright: (C) 2022 by the author. Licensee MDPI, Basel, Switzerland. This article is an open access article distributed under the terms and conditions of the Creative Commons Attribution (CC BY) license (https:// creativecommons.org/licenses/by/ $4.0 /)$.
Curricula and Instructions Department, College of Education, King Faisal University, Al-Ahsa 31982, Saudi Arabia; mahdi@kfu.edu.sa

\begin{abstract}
Students' learning environments are significantly influenced by massive open online courses (MOOCs). To better understand how students could implement learning technology for educational purposes, this study creates a structural equation model and tests confirmatory factor analysis. Therefore, the aim of this study was to develop a model through investigating observability $(\mathrm{OB})$, complexity (CO), trialability (TR), and perceived usefulness (PU) with perceived ease-of-use (PEU) of MOOCs adoption by university students to measure their academic self-efficacy (ASE), learning engagement (LE), and learning persistence (LP). As a result, the study used an expanded variant of the innovation diffusion theory (IDT) and the technology acceptance model (TAM) as the research model. Structural Equation Modeling (SEM) with Smart-PLS was applied to quantitative data collection and analysis of 540 university students as respondents. Student responses were grouped into nine factors and evaluated to decide the students' ASE, LE, and LP. The findings revealed a clear correlation between $\mathrm{OB}, \mathrm{CO}$, and TR, all of which were important predictors of PU and PEU. Students' ASE, LE, and LP were affected by PEU and PU. This study's established model was effective in explaining students' ASE, LE, and LP on MOOC adoption. These findings suggest implications for designing and developing effective instructional and learning strategies in MOOCs in terms of learners' perceptions of themselves, their instructors, and learning support systems.
\end{abstract}

Keywords: IDT; TAM; SEM; MOOCs; learning engagement; learning persistence

\section{Introduction}

MOOCs have had a lot of coverage to extend higher education options and increase the quality of teaching and learning during COVID-19 pandemic. Thus, there have been many efforts to popularize higher education to aid society's transition into digital learning during COVID-19 pandemic. MOOCs are online learning environments that enable students to take courses on a wide range of subjects with no limitations and at a low cost [1]. MOOCs have had free access to esteemed professors' seminars as well as ongoing learning support through a variety of events and rich learning materials during the COVID-19 pandemic. MOOCs provide for open enrollment, curriculum sharing, and adaptive outcomes. MOOCs also provide public engagement, usable interactive assets that are verified by leading experts in the field. Additionally, MOOCs are built on the engagement of students based on their learning goals, prior knowledge and skills, and shared benefits [2]. MOOCs are gaining popularity among students due to several benefits. MOOCs, for example, are readily available to learners from all over the world through the Internet since they are online [3]. Furthermore, MOOCs provide learners with free or low-cost access to prestigious institutions without any eligibility requirements [4]. MOOCs have been shown to improve learning motivation by exposing students to a variety of free learning methods [5]. According to Shah [6], there has been a substantial surge in MOOC enrollment, with student enrollment reaching 101 million in 2018, up 30\% from 2017. Furthermore, it has been suggested that higher education institutions that provide 
MOOCs can fail to provide courses with a broad range of content due to the different levels of available resources or prior experience on the part of students, as well as their level of learning motivation [7]. Because of the rising enrolment rates in MOOCs around the world, experts say it is critical to assess students' readiness to engage [8]. Many academics have conducted studies to determine if students are ready to adopt MOOCs during the COVID-19 pandemic, which have become really important for students from all over the world [9]. Previous research has looked at the factors that influence MOOC learning engagement (LE) and learning persistence (LP) [10]. Most of the studies, on the other hand, looked at how learners' qualities, such as motivation, influenced MOOC learning outcomes [11]. Previous research has focused on determining which specific factors affected these MOOC learning outcomes from the perspectives of learners, teachers, and learning support systems. However, several experiments have shown that the MOOC learning environment can be examined holistically, looking at the impact of all its facets on MOOC learning outcomes [12]. An MOOC is a type of learning environment in which several different elements interact with one another. To address such issues, researchers must examine the MOOC learning phenomenon holistically, taking into account the learner, the instructor, and the learning support environment. To achieve this, it is important to investigate the variables that influence LE and the ability to adopt learning in an MOOC from a broad perspective, as well as the relationships between them. As a result of this research, a comprehensive model was developed that describes MOOC learning outcomes by defining structural relationships between the outcomes and the variables that influence them, based on LE and LP as results, given the key problems with MOOC use during the COVID-19 pandemic. Also, this research advances technology acceptance model (TAM) literature by looking into the relationship between the novelty of TAM variables and the diffusion theory in a related model. The study proposes innovation diffusion theory (IDT) as a contextual theory to investigate the impact of positive influences on TAM concepts.

\section{Theoretical Model and Hypothesis Development}

TAM and IDT are similar in some theories and complement each other in terms of observing information system implementation. Scholars clarify that the theories used in TAM are a subset of perceived innovation features; hence, combining these two models may result in a more stable model than one model alone [13]. TAM models have been shown to be able to clarify technology adoption in a variety of ways, including social network applications [14] and health informatics [15]. The models have also been used in MOOCs and other smart learning systems to research and improve them [16-20]. For example, Refs. [20-23] compared the behavioral intention trends of conventional e-learning systems and MOOCs and discovered that sense of society and perceived benefits affect learners' behavioral intention in both general e-learning systems and MOOCs. According to Fianu et al. [24], computer self-efficacy, success expectancy, and system quality influence MOOC use intention, while facilitating conditions, instructional quality, and MOOC usage intention influence MOOC usage. Many researchers contend that the TAM models are effectively a subset of the IDT, and that combining the two models will result in a model that is much more effective than either alone [25-27]. Since the concepts of IDT and TAM are so similar and complementary, researchers suggested the IDT and TAM models be combined to take advantage of the benefits of both theoretical models while analyzing the innovation acceptance process. As a result, the IDT and TAM integrated paradigm has been used in several areas to help students implement new concepts. Additionally, previous studies that integrated the two theories, showed outstanding results $[13,26,28]$. As a result, this research uses two main theoretical models, IDT [29] and TAM [30]. Therefore, this research studied the following factors: observability $(\mathrm{OB})$, complexity $(\mathrm{CO})$, trialability (TR), perceived ease-of-use (PEU), perceived usefulness (PU), academic self-efficacy (ASE), learning engagement (LE), and learning persistence (LP). See Figure 1. 


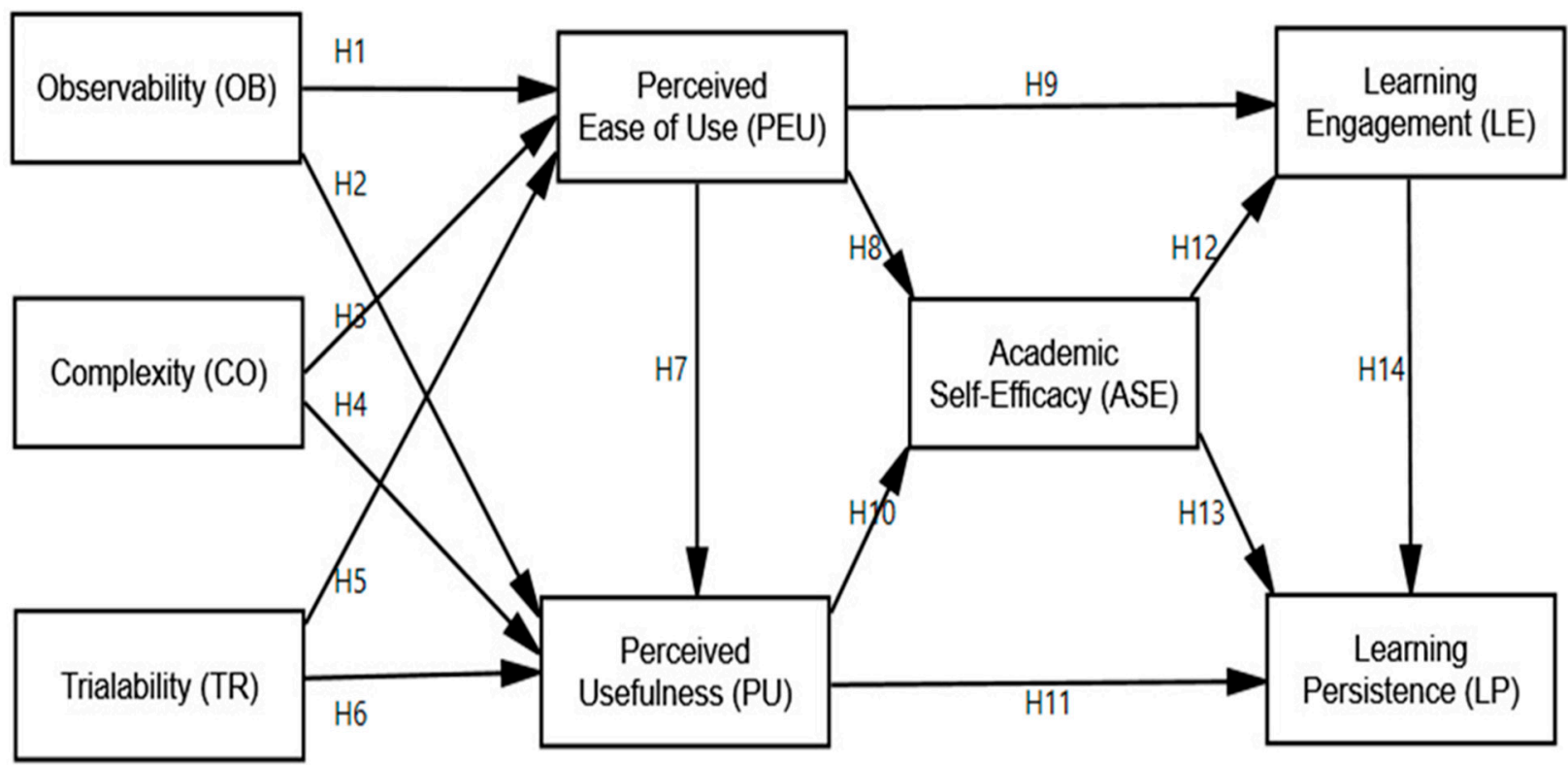

Figure 1. Research model and hypotheses.

\subsection{Observability $(O B)$}

The degree to which an innovation's outcomes are visible is known as OB [29]. Al-Rahmi et al. [31] analyzed the correlation between OB and PU and the results encouraged students to use MOOC systems during the COVID-19 pandemic. They also discovered that $\mathrm{OB}$ has little impact on PU, which contradicted previous research. The hypothesis proposed for this construct is that OB of using MOOC systems is positively influenced by PU and PEU.

\subsection{Complexity (CO)}

The perceived degree of effort needed by end-users to understand technologies and their ease-of-use is referred to as CO. As a result, in this study, $\mathrm{CO}$ is described as the degree to which a student perceives difficulties in using the MOOC system during the COVID-19 pandemic, which affects their learning output. The student's intention to use the MOOC system seems to decline as the MOOC system becomes more complex [32]. Furthermore, observational research showed that the $\mathrm{CO}$ of the MOOC system has a significant negative impact on the attitude about using the system and the behavior strategy for using it [33]. The hypothesis proposed for this construct is that CO of using MOOC systems is positively influenced by PU and PEU.

\subsection{Trialability $(T R)$}

TR refers to how comfortable society with the probability of observing inventions before deciding whether or not to consider them. To everyone who is seeing it for implementation or using it to learn, a trialable innovation symbolizes no uncertainty. As a result, TR is defined in this study as the degree to which a student views the acceptability of MOOC system use as influencing their learning output during the COVID-19 pandemic. Some studies have extensively confirmed the correlation between TR and attitude toward using the method MOOCs [26,33]. The hypothesis proposed for this construct is that TR in the use of MOOCs systems is positively influenced by PU and PEU.

\subsection{Perceived Ease-of-Use (PEU)}

Davis [30] described PEU as "the degree to which someone has trust in using a particular system with little effort". As a result, in this study, PEU is described as the degree to which a student believes MOOCs are easy to use and will enhance their learning efficiency during the COVID-19 pandemic. In the literature, ease-of-use refers to the 
degree to which a person believes that using a specific device requires little effort [30]. The hypothesis proposed for this construct is that PEU of MOOC systems is positively influenced by PU, students' ASE, LE, and LP.

\subsection{Perceived Usefulness (PU)}

PU is described by Davis [30] as the degree to which someone believes that implementing a particular scheme can enhance work performance. As a result, in this study, $\mathrm{PU}$ is described as the degree to which a student believes that using MOOCs can improve their learning efficiency during the COVID-19 pandemic. Modern research on MOOC use [34-37] has also reported that PU has a major impact on use MOOCs. The hypothesis proposed for this construct is that PU in the use of MOOC systems is positively influenced by students' ASE, LE, and LP.

\subsection{Academic Self-Efficacy (ASE)}

ASE is described as students' self-reported trust in their MOOC performance. It is a key indicator of self-regulation and online academic success [38], as well as a mediator that links learners' motivation with actions [39]. In several contexts, including e-learning, ASE has been shown to affect LE and success. ASE has been found to have an important impact on student engagement $[40,41]$ and LP in many studies [42,43]. Given the long duration of courses and the high degree of autonomy, learners' ASE is predicted to play a significant role in their engagement and persistence in MOOCs [44]. The hypothesis proposed for this construct is that students' ASE in the use of MOOC systems is positively influenced by LE and LP during the COVID-19 pandemic.

\subsection{Learning Engagement (LE)}

$\mathrm{LE}$, which is the continuous initiative that a learner expends in the learning process to achieve learning goals, is the most widely used metric to assess learning outcomes in MOOCs [45]. Furthermore, rather than a single dimension, such as actions, LE usually consists of multidimensional variables such as motivation, awareness, and attitude [46]. While a number of MOOC engagement models have been developed and validated, the majority of them focus on the behavioral dimensions of LE rather than the multifaceted aspects of LE. However, in order to successfully develop a strategy for encouraging LE in MOOCs as a whole, an enhancement the capability to the social, cognitive, and behavioral elements of LE is necessary $[47,48]$. The hypothesis proposed for this construct is that students' LE in the use of MOOC systems is positively influenced by LP during COVID-19 pandemic.

\subsection{Learning Persistence (LP)}

$\mathrm{LP}$ is categorized into two types: the intention to finish the present course and the intention to take another course later [49]. LP has received a lot of attention because it is a multidimensional measure of a learner's motivations, attitudes, intelligence, and behaviors; it necessitates addressing the temptations and challenges that arise during the learning process in order to keep learning going [41]. LP is an MOOC result that refers to learners' ability to finish learning activities they begin, such as finishing courses they engaged in or earning degrees [50]. MOOC completion rates have been studied in recent years, mostly in relation to persistence in MOOC learning environments. Reich et al. [51] discovered that the overall MOOC use during the COVID-19 pandemic was 3.2 percent, which was similar to [52].

\section{Research Methodology}

Many universities around the world have promoted the use of available MOOCs in education. Therefore, through an empirical investigation of undergraduate and postgraduate students who used MOOCs for education during the COVID-19 pandemic, this research aims to establish a model for the measurement of LE and LP. For objects containing the IDT and TAM constructs and demographic characteristics, a five-point Likert scale 
ranging from 1 (strongly disagree) to 5 (strongly agree) was used. For survey delivery, self-administration was used, and respondents were asked to provide input on the use of MOOCs for education and how this affected LE and LP. The data were then analyzed using the Statistical Package for the Social Sciences (SPSS) and Structural Equation Modeling (Smart-PLS-SEM) to validate the measurement model's validity and reliability. Factor loadings were used to ensure construct validity, composite reliability, Cronbach's alpha, and convergence validity for the model's goodness of fit, as recommended by [53]. Based on standardized products, Cronbach's alpha was found to be 0.922 . The reliability coefficient (Cronbach's alpha) for both pilot and final test constructs is shown in Table 1: all variables were found to be accurate and reasonable. See Table 1 for more information.

Table 1. Reliability coefficient for all constructs in pilot test and final test.

\begin{tabular}{ccccc}
\hline No. & Latent Variables & Code & Pilot Test & Final Test \\
\hline 1 & Observability & OB & 0.882 & 0.907 \\
2 & Complexity & CO & 0.793 & 0.922 \\
3 & Trialability & TR & 0.798 & 0.872 \\
4 & Perceived ease-of-use & PEU & 0.801 & 0.911 \\
5 & Perceived usefulness & PU & 0.851 & 0.905 \\
6 & Academic self-efficacy & ASE & 0.782 & 0.893 \\
7 & Learning engagement & LE & 0.728 & 0.890 \\
8 & Learning persistence & LP & 0.812 & 0.917 \\
\hline
\end{tabular}

\subsection{Sample Characteristics and Data Collection}

This study was conducted online from November 2020 to February 2021, when universities were closed due to the COVID-19 pandemic. Prior to the main data collection, a survey instrument was developed and validated to measure factors predicting student use of MOOCs for education. A total of 561 questionnaires was distributed among students at King Faisal University. After the normality test, however, 21 participants' responses were omitted; such exclusions were suggested by [53], who claimed that outliers can lead to incorrect statistical results and must be removed. As a result, 540 participants' responses were imported into the SPSS package program. This study focused on postgraduate and undergraduate students who were active users of MOOCs for education during the COVID-19 pandemic. To ensure the model's validity, confirmatory factor analysis was used.

\subsection{Measurement Instruments}

The build items adopted from previous studies confirmed the measurement scales' material validity. There were two sections to the research questionnaire: basic demographic data was collected via questionnaire pieces (gender, age, educational level, and specialization) and questionnaire items measuring $\mathrm{OB}$ taken from [54], $\mathrm{CO}$ taken from [55], TR taken from [56], PEU and PU taken from [30], ASE taken from [57], LE taken from [58], and LP from [50]. All of the instruments were from a trustworthy source. As a result, self-report on multi-item scales derived from previous studies was used to assess the variables. All of the measures were graded on a five-point Likert scale, with 1 indicating "strongly disagree" and 5 indicating "strongly agree". Table 3 shows the measurement model and item loadings, as well as an appendix showing the questionnaire.

\section{Results and Analysis}

The Cronbach's alpha reliability coefficient was 0.907 , meaning that the factors influencing students' ASE, LE, and LP were reliable. Discriminant validity was evaluated using three parameters. Variable indices must be less than 0.70, each construct's average variance extracted (AVE) must be equal to or greater than 0.5 , and the AVE square root must be greater than the inter-construct correlations (IC) for a factor, as recommended by [53]. Apart from the above considerations, build factor analysis results with factor loadings of 0.70 or higher (Cronbach's alpha 0.70 and composite reliability 0.70 ) are satisfactory [53]. 


\subsection{Demographic Information}

The demographic data are presented in Table 2. There were 243 male respondents $(45.0 \%)$ and 297 female respondents (55.0\%). Of these, $115(21.3 \%)$ were between 18 and 20 years old, $309(57.2 \%)$ between 21 and 25 years old, $52(9.6 \%)$ between 26 and 31 years old, and 64 (11.9\%) more than 32 years old. Regarding the level of education, 375 (69.4\%) were undergraduate students, and 165 (30.6\%) were postgraduate students. Social science accounted for 227 (42.0\%) of respondents, and technology 313 (58.0\%). Finally, 535 (99.1\%) of respondents used MOOCs, and $5(0.9 \%)$ did not use MOOCs for LE and LP during the COVID-19 pandemic.

Table 2. Demographic data.

\begin{tabular}{cccccc}
\hline Factors & Frequency & Percentage & Factors & Frequency & Percentage \\
\hline Male & 243 & $45.0 \%$ & Undergraduate & 375 & $69.4 \%$ \\
Female & 297 & $55.0 \%$ & Postgraduate & 165 & $30.6 \%$ \\
$18-20$ & 115 & $21.3 \%$ & Social science & 227 & $42.0 \%$ \\
$21-25$ & 309 & $57.2 \%$ & Technology & 313 & $58.0 \%$ \\
$26-31$ & 52 & $9.6 \%$ & Used MOOCs & 535 & $99.1 \%$ \\
$<32$ & 64 & $11.9 \%$ & Did not use MOOCs & 5 & $0.9 \%$ \\
\hline
\end{tabular}

\subsection{Measurement Construct Validity}

The degree to which individual objects judge the definition with which they were developed is referred to as build validity [59]. This was determined by a thorough examination of previously tested items in the literature. Table 3 shows the objects and their loadings that must be loaded into the build they were created to evaluate [60].

Table 3. Measurement model and item loadings.

\begin{tabular}{|c|c|c|c|c|c|c|c|c|c|}
\hline Factors & Items & $\mathbf{L P}$ & ASE & LE & $\mathrm{CO}$ & TR & OB & PEU & PU \\
\hline \multirow{4}{*}{$\begin{array}{l}\text { Learning } \\
\text { persistence }\end{array}$} & LP1 & 0.866587 & 0.409229 & 0.456949 & 0.496756 & 0.507621 & 0.442898 & 0.520736 & 0.438724 \\
\hline & LP2 & 0.857857 & 0.378168 & 0.442198 & 0.411245 & 0.423364 & 0.374647 & 0.523267 & 0.398112 \\
\hline & LP3 & 0.739077 & 0.341676 & 0.386315 & 0.300873 & 0.352027 & 0.382555 & 0.456835 & 0.374641 \\
\hline & LP4 & 0.846997 & 0.484622 & 0.437832 & 0.419349 & 0.466017 & 0.440385 & 0.603844 & 0.509227 \\
\hline \multirow{3}{*}{$\begin{array}{l}\text { Academic } \\
\text { self-efficacy }\end{array}$} & ASE1 & 0.404020 & 0.869193 & 0.441794 & 0.402094 & 0.324107 & 0.344169 & 0.512119 & 0.426004 \\
\hline & ASE2 & 0.397449 & 0.869435 & 0.347720 & 0.333559 & 0.456661 & 0.323705 & 0.558149 & 0.414815 \\
\hline & ASE3 & 0.472983 & 0.864665 & 0.439849 & 0.454008 & 0.467404 & 0.374204 & 0.534142 & 0.424820 \\
\hline \multirow{4}{*}{$\begin{array}{c}\text { Learning } \\
\text { engagement }\end{array}$} & LE1 & 0.468615 & 0.402847 & 0.773471 & 0.586757 & 0.398936 & 0.441979 & 0.461002 & 0.351077 \\
\hline & LE2 & 0.431767 & 0.377146 & 0.842908 & 0.478700 & 0.283175 & 0.362616 & 0.386248 & 0.320366 \\
\hline & LE3 & 0.334729 & 0.357091 & 0.775424 & 0.340261 & 0.273455 & 0.349890 & 0.317954 & 0.257263 \\
\hline & LE4 & 0.411071 & 0.372981 & 0.808421 & 0.398818 & 0.316303 & 0.371903 & 0.364595 & 0.283206 \\
\hline \multirow{3}{*}{ Complexity } & $\mathrm{CO} 1$ & 0.415164 & 0.358333 & 0.488154 & 0.879592 & 0.319914 & 0.282163 & 0.344512 & 0.371541 \\
\hline & $\mathrm{CO} 2$ & 0.437509 & 0.405266 & 0.500264 & 0.904889 & 0.339386 & 0.338469 & 0.406838 & 0.339103 \\
\hline & $\mathrm{CO} 3$ & 0.465971 & 0.457375 & 0.543941 & 0.882279 & 0.411537 & 0.376236 & 0.437478 & 0.323749 \\
\hline \multirow{3}{*}{ Trialability } & TR1 & 0.485979 & 0.452026 & 0.332503 & 0.322903 & 0.876708 & 0.376194 & 0.505611 & 0.431658 \\
\hline & TR2 & 0.443479 & 0.379920 & 0.329258 & 0.334049 & 0.882441 & 0.366163 & 0.487563 & 0.362972 \\
\hline & TR3 & 0.453602 & 0.416968 & 0.391362 & 0.397439 & 0.847543 & 0.355069 & 0.473975 & 0.347456 \\
\hline \multirow{3}{*}{ Observability } & OB1 & 0.434800 & 0.355466 & 0.407970 & 0.332201 & 0.377124 & 0.875863 & 0.349526 & 0.361888 \\
\hline & OB2 & 0.425504 & 0.342370 & 0.400506 & 0.321056 & 0.325686 & 0.899493 & 0.404596 & 0.380570 \\
\hline & OB3 & 0.449840 & 0.361935 & 0.456838 & 0.337554 & 0.406854 & 0.868979 & 0.467352 & 0.415286 \\
\hline
\end{tabular}


Table 3. Cont.

\begin{tabular}{|c|c|c|c|c|c|c|c|c|c|}
\hline Factors & Items & LP & ASE & LE & $\mathrm{CO}$ & TR & OB & PEU & PU \\
\hline \multirow{4}{*}{$\begin{array}{l}\text { Perceived } \\
\text { ease-of-use }\end{array}$} & PEU1 & 0.521841 & 0.566228 & 0.363640 & 0.356249 & 0.445497 & 0.335581 & 0.839448 & 0.497397 \\
\hline & PEU2 & 0.571014 & 0.540729 & 0.445640 & 0.422644 & 0.476066 & 0.418695 & 0.872445 & 0.524587 \\
\hline & PEU3 & 0.551761 & 0.500985 & 0.434654 & 0.397190 & 0.512537 & 0.417787 & 0.877635 & 0.515299 \\
\hline & PEU4 & 0.571147 & 0.532751 & 0.435381 & 0.374902 & 0.520285 & 0.445804 & 0.882027 & 0.516214 \\
\hline \multirow{4}{*}{$\begin{array}{l}\text { Perceived } \\
\text { usefulness }\end{array}$} & PU1 & 0.370463 & 0.389302 & 0.304713 & 0.310555 & 0.312962 & 0.360937 & 0.434173 & 0.757177 \\
\hline & PU2 & 0.448210 & 0.389434 & 0.340550 & 0.332553 & 0.372310 & 0.341246 & 0.490487 & 0.823234 \\
\hline & PU3 & 0.457722 & 0.404203 & 0.320772 & 0.359266 & 0.396738 & 0.377763 & 0.497111 & 0.851759 \\
\hline & PU4 & 0.390722 & 0.373186 & 0.255783 & 0.228691 & 0.319618 & 0.327951 & 0.468260 & 0.763029 \\
\hline
\end{tabular}

\subsection{Measurement Validity Convergent}

Since the factor loadings of 28 items were greater than 0.70 and their composite reliability was greater than 0.70 , ranging from 0.924393 to 0.876110 , they were considered suitable. The Cronbach's alpha coefficient values ranged from 0.890856 to 0.810931 , meaning that the results were acceptable. The AVE numbers ranged from 0.790308 to 0.639303 . The results of the Confirmatory factor analysis (CFA) are mentioned in [53] and shown in Table 4.

Table 4. Factor loadings and confirmatory factor analysis results.

\begin{tabular}{|c|c|c|c|c|c|c|}
\hline Factors & Items & Factor Loadings & AVE & Composite Reliability & Cronbach's Alpha & R Square \\
\hline \multirow{4}{*}{$\begin{array}{c}\text { Learning } \\
\text { persistence }\end{array}$} & LP1 & 0.866587 & \multirow{4}{*}{0.687633} & \multirow{4}{*}{0.897660} & \multirow{4}{*}{0.847300} & \multirow{4}{*}{0.418553} \\
\hline & LP2 & 0.857857 & & & & \\
\hline & LP3 & 0.739077 & & & & \\
\hline & LP4 & 0.846997 & & & & \\
\hline \multirow{3}{*}{$\begin{array}{l}\text { Academic } \\
\text { self-efficacy }\end{array}$} & ASE1 & 0.869193 & \multirow{3}{*}{0.753020} & \multirow{3}{*}{0.901445} & \multirow{3}{*}{0.836172} & \multirow{3}{*}{0.402374} \\
\hline & ASE2 & 0.869435 & & & & \\
\hline & ASE3 & 0.864665 & & & & \\
\hline \multirow{4}{*}{$\begin{array}{c}\text { Learning } \\
\text { engagement }\end{array}$} & LE1 & 0.773471 & \multirow{4}{*}{0.640895} & \multirow{4}{*}{0.876996} & \multirow{4}{*}{0.813886} & \multirow{4}{*}{0.284242} \\
\hline & LE2 & 0.842908 & & & & \\
\hline & LE3 & 0.775424 & & & & \\
\hline & LE4 & 0.808421 & & & & \\
\hline \multirow{3}{*}{ Complexity } & $\mathrm{CO} 1$ & 0.879592 & \multirow{3}{*}{0.790308} & \multirow{3}{*}{0.918731} & \multirow{3}{*}{0.867320} & \multirow{3}{*}{0.000000} \\
\hline & $\mathrm{CO} 2$ & 0.904889 & & & & \\
\hline & $\mathrm{CO} 3$ & 0.882279 & & & & \\
\hline \multirow{3}{*}{ Trialability } & TR1 & 0.876708 & \multirow{3}{*}{0.755216} & \multirow{3}{*}{0.902466} & \multirow{3}{*}{0.838050} & \multirow{3}{*}{0.000000} \\
\hline & TR2 & 0.882441 & & & & \\
\hline & TR3 & 0.847543 & & & & \\
\hline \multirow{3}{*}{ Observability } & OB1 & 0.875863 & \multirow{3}{*}{0.777116} & \multirow{3}{*}{0.912722} & \multirow{3}{*}{0.857333} & \multirow{3}{*}{0.000000} \\
\hline & OB2 & 0.899493 & & & & \\
\hline & OB3 & 0.868979 & & & & \\
\hline \multirow{4}{*}{$\begin{array}{c}\text { Perceived } \\
\text { ease-of-use }\end{array}$} & PEU1 & 0.839448 & \multirow{4}{*}{0.753555} & \multirow{4}{*}{0.924393} & & \\
\hline & PEU2 & 0.872445 & & & & \\
\hline & PEU3 & 0.877635 & & & 0.890856 & 0.498930 \\
\hline & PEU4 & 0.882027 & & & & \\
\hline
\end{tabular}


Table 4. Cont.

\begin{tabular}{ccccccc}
\hline Factors & Items & Factor Loadings & AVE & Composite Reliability & Cronbach's Alpha & R Square \\
\hline & PU1 & 0.757177 & & & \\
\multirow{2}{*}{$\begin{array}{c}\text { Perceived } \\
\text { usefulness }\end{array}$} & PU2 & 0.823234 & & & & \\
& PU3 & 0.851759 & 0.639303 & 0.876110 & 0.810931 & 0.299832 \\
\cline { 2 - 3 } & PU4 & 0.763029 & & & \\
\hline
\end{tabular}

\subsection{Measurement Validity That Is Convergent}

Discriminant validity refers to the differences between sets of concepts and their measures. As required by [61], the discriminant validity of all constructs was checked with values greater than 0.50 and significant at $p=0.001$. The AVE square root shared by objects in a single construct should be smaller than the similarities between items in the two constructs, according to Table 5 [53].

Table 5. Discriminant validity.

\begin{tabular}{|c|c|c|c|c|c|c|c|c|c|}
\hline Factors & Code & ASE & $\mathrm{CO}$ & LE & LP & OB & PEU & PU & TR \\
\hline Academic self-efficacy & ASE & 1.000 & & & & & & & \\
\hline Complexity & $\mathrm{CO}$ & 0.459 & 1.000 & & & & & & \\
\hline Learning engagement & LE & 0.474 & 0.575 & 1.000 & & & & & \\
\hline Learning persistence & $\mathrm{LP}$ & 0.491 & 0.495 & 0.520 & 1.000 & & & & \\
\hline Observability & OB & 0.401 & 0.375 & 0.481 & 0.496 & 1.000 & & & \\
\hline Perceived ease-of-use & PEU & 0.616 & 0.447 & 0.484 & 0.639 & 0.467 & 1.000 & & \\
\hline Perceived usefulness & PU & 0.486 & 0.387 & 0.383 & 0.523 & 0.440 & 0.592 & 1.000 & \\
\hline Trialability & TR & 0.480 & 0.403 & 0.403 & 0.531 & 0.421 & 0.563 & 0.440 & 1.000 \\
\hline
\end{tabular}

\subsection{The Analysis of the Structural Model}

To validate the research hypotheses and examine build relationships, Smart PLS 2.0 was used. The hypothesis is seen in Figure 1, the path coefficient findings in Figure 2, and the path coefficient (T-Values) findings in Figure 3.

Based on the results shown in Table 6, the relationship between OB -> PEU (H1) was ( $\beta=0.227593, t=2.310959, p<0.001)$, thus, the hypothesis was accepted. Similarly, the relationship between $\mathrm{OB}->\mathrm{PU}(\mathrm{H} 2)$ was $(\beta=0.169129, \mathrm{t}=1.627382, p<0.001)$, thus, the hypothesis was accepted. Additionally, the relationship between CO $\rightarrow$ PEU (H3) was $(\beta=0.207059, \mathrm{t}=1.984904, p<0.001)$, thus, the hypothesis was accepted, and the relationship between CO $\rightarrow$ PU $(\mathrm{H} 4)$ was $(\beta=0.100052, \mathrm{t}=1.858425, p<0.001)$, thus, the hypothesis was accepted. Moreover, the relationship between TR $->$ PEU (H5) was $(\beta=0.384113$, $\mathrm{t}=3.586038, p<0.001)$, thus, the hypothesis was accepted. Also, the relationship between TR $->$ PU $(\mathrm{H} 6)$ was $(\beta=0.095139, \mathrm{t}=1.926868, p<0.001)$, thus, the hypothesis was accepted. Furthermore, the relationship between PEU $\rightarrow$ PU $(H 7)$ was $(\beta=0.414214, t=4.020760$, $p<0.001)$, thus, the hypothesis was accepted, and the relationship between PEU $\rightarrow$ ASE (H8) was $(\beta=0.504820, t=5.777300, p<0.001)$, thus, the hypothesis was accepted. Similarly, the relationship between PEU $\rightarrow$ LE $(\mathrm{H} 9)$ was $(\beta=0.310484, \mathrm{t}=2.192627, p<0.001)$, thus, the hypothesis was accepted. Additionally, the relationship between PU -> ASE (H10) was $(\beta=0.187772, t=1.939450, p<0.001)$, thus, the hypothesis was accepted, and the relationship between PU $->$ LP $(\mathrm{H} 11)$ was $(\beta=0.310231, t=3.031242, p<0.001)$, thus, the hypothesis was accepted. Moreover, the relationship between ASE $->$ LE (H12) was ( $\beta=0.282570$, $\mathrm{t}=2.086258, p<0.001)$, thus, the hypothesis was accepted. Similarly, the relationship between ASE $->$ LP $(\mathrm{H} 13)$ was $(\beta=0.193224, \mathrm{t}=1.782361, p<0.001)$, thus, the hypothesis was accepted. Finally, the relationship between LE -> LP (H14) was $(\beta=0.310114, t=3.145690$, $p<0.001)$, thus, the hypothesis was accepted. 


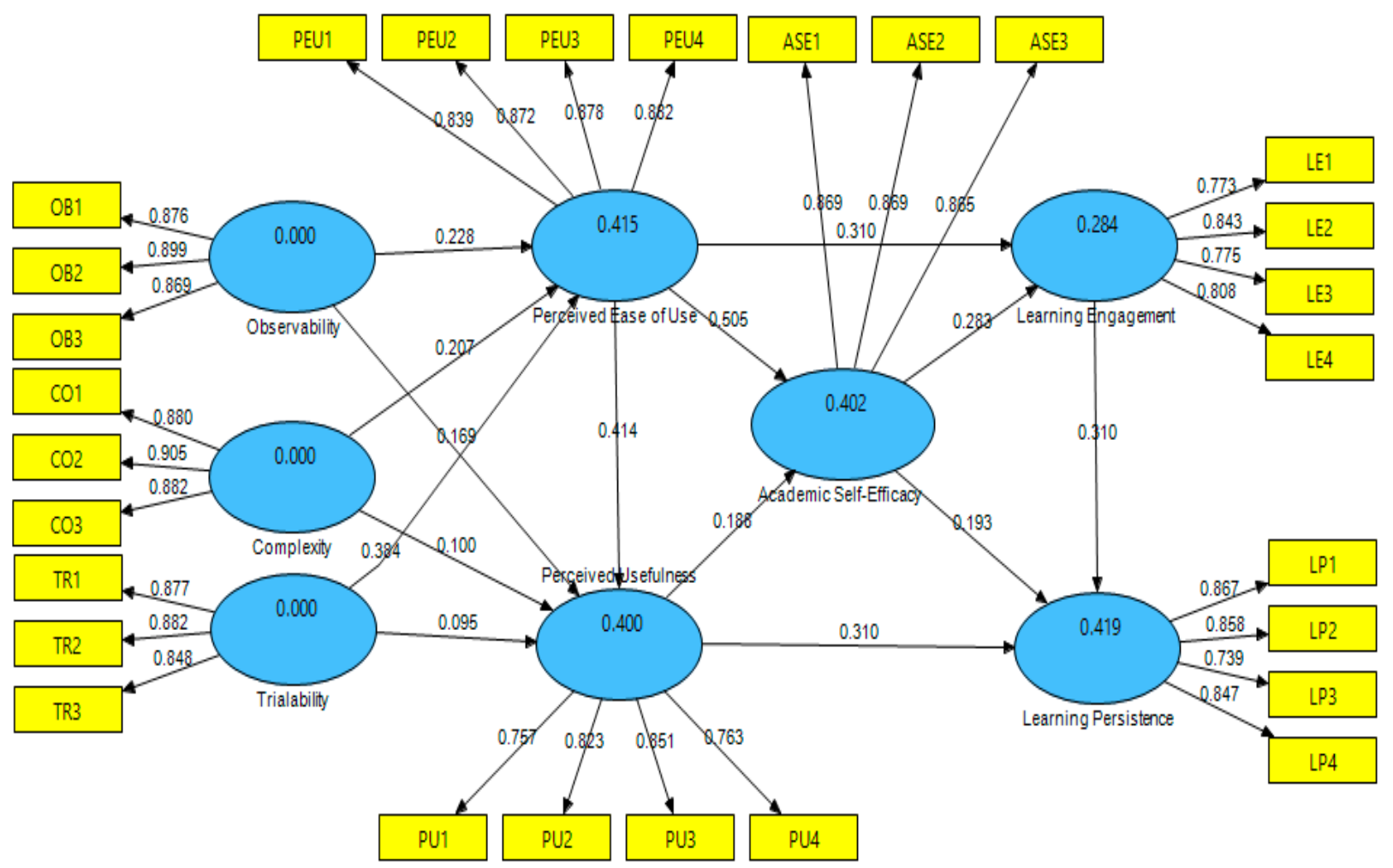

Figure 2. Path coefficient results.

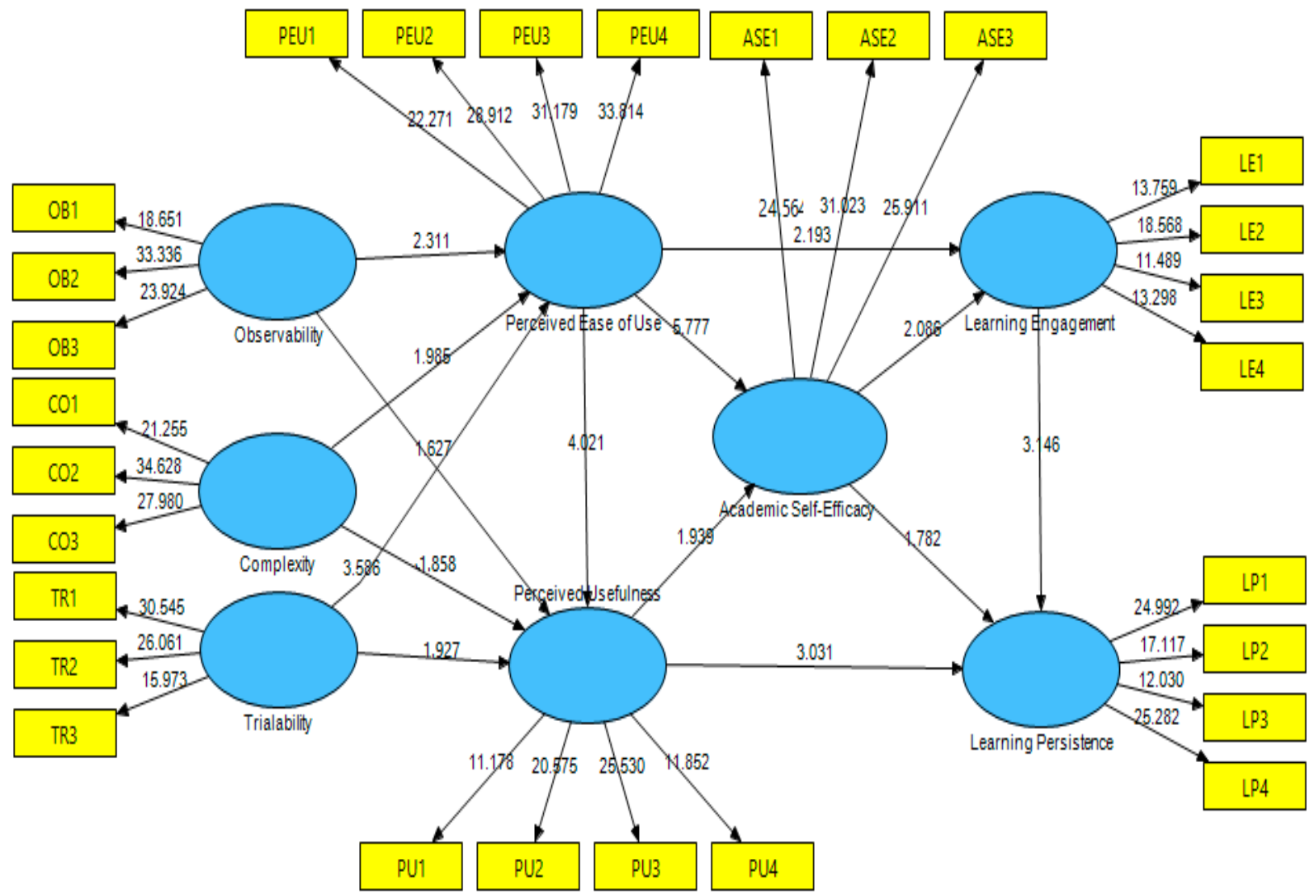

Figure 3. Path T-values. 
Table 6. Hypotheses testing.

\begin{tabular}{ccccc}
\hline Path and Hypotheses & Path Coefficient & Standard Error & T Values & Results \\
\hline OB -> PEU (H1) & 0.227593 & 0.098484 & 2.310959 & Accepted \\
OB -> PU (H2) & 0.169129 & 0.103927 & 1.627382 & Accepted \\
CO -> PEU (H3) & 0.207059 & 0.104317 & 1.984904 & Accepted \\
CO -> PU (H4) & 0.100052 & 0.116553 & 1.858425 & Accepted \\
TR -> PEU (H5) & 0.384113 & 0.107114 & 3.586038 & Accepted \\
TR -> PU (H6) & 0.095139 & 0.102646 & 1.926868 & Accepted \\
PEU -> PU (H7) & 0.414214 & 0.103019 & 4.020760 & Accepted \\
PEU -> ASE (H8) & 0.504820 & 0.087380 & 5.777300 & Accepted \\
PEU - > LE (H9) & 0.310484 & 0.141604 & 2.192627 & Accepted \\
PU -> ASE (H10) & 0.187772 & 0.096817 & 1.939450 & Accepted \\
PU -> LP (H11) & 0.310231 & 0.102345 & 3.031242 & Accepted \\
ASE -> LE (H12) & 0.282570 & 0.135444 & 2.086258 & Accepted \\
ASE -> LP (H13) & 0.193224 & 0.108409 & 1.782361 & Accepted \\
LE -> LP (H14) & 0.310114 & 0.098584 & 3.145690 & Accepted \\
\hline
\end{tabular}

\section{Discussion and Implications}

The aim of this study was to develop a model through investigating observability $(\mathrm{OB})$, complexity (CO), trialability (TR), and perceived usefulness (PU) with perceived ease-of-use (PEU) on MOOC adoption by university students to measure their ASE, LE, and LP. As a result, this study used an expanded variant of the innovation diffusion theory (IDT) and the technology acceptance model (TAM) as the research model. Therefore, this study was a first-of-its-kind attempt to incorporate IDT into a TAM model. The relationships between three variables, PU and PEU, and students' ASE, LE, and LP, were investigated using the proposed model. In general, the findings corroborated the study paradigm and hypothesis. The findings of this study shed light on the IDT, which states that $\mathrm{OB}, \mathrm{CO}$, and TR influence TAM factors' PEU and usefulness. The results also revealed that students' ASE, LE, and LP in using MOOC systems during the COVID-19 pandemic increased as a result of their PU and ease-of-use. OB, CO, and TR were also found to play a role in PU and PEU of MOOCs, which affected students' ASE, LE, and LP. Students' ASE was also confirmed by the use of MOOC systems during the COVID-19 pandemic for LE and LP by university students, according to the results. The findings verified previous studies that found $\mathrm{OB}$, $\mathrm{CO}$, and TR had major positive effects on PU and ease-of-usage. It should be assumed that prior to deciding to use the MOOC system during the COVID-19 pandemic, students can evaluate whether the MOOC system will suit their research needs or be suitable for their studies. If the MOOC systems are able to satisfy students' research needs, they will consider the MOOC system to be helpful during the COVID-19 pandemic. Specifically, the lower the PEU, the greater the TR. Nonetheless, the test findings were not the same as in previous reports $[34,62]$. Because of the disparities in results, further research into the interaction between these two structures is needed. Our findings, on the other hand, strongly supported the hypothesis that perceived compatibility had a positive impact on PEU. Furthermore, PU and PEU was significantly influenced by OB and TR. These findings are consistent with previous research $[63,64]$ where students' ASE, LE, and LP were all influenced by TAM, PU, and PEU. That was also the case in this study, where MOOC device users believed that higher PU, and PEU had a positive direct impact on PU. These observations were similar to those of Venkatesh et al. [65]. This research discovered that students would be wary of MOOCs if they thought they would make their studies more difficult and unpleasant. It was concluded that if students believed that MOOCs would aid their academic performance, they would consider MOOCs to be simple to use. Furthermore, as students have the opportunity to check out MOOC systems during the COVID-19 pandemic, they are more likely to consider the MOOC system to be more userfriendly. In summary, the results show perceived compatibility between system features and the user's need to increase MOOCs acceptance. Students' ASE, LE, and LP are all affected by influences such as OB, difficulty, and TR [30,66-68]. This supports recent results 
for MOOC systems [69]. Similarly, three analytical pieces of evidence are presented in this study. The first empirical evidence of the MOOC system came in the form of PU and ease-ofuse, the second was evidence of students' ASE, as measured by PU and ease-of-use, which may influence LE and persistence. The third empirical evidence that PU and PEU of MOOC systems can influence students' ASE to use MOOC systems came through OB, CO, and TR. In the educational context, there was substantial theoretical contribution to previous IDT with TAM [70-75]. Education must leave the door open and make it possible to question the entire idea of sustainable development as the right path and inspire the students of today and tomorrow to create new visions and paradigms to make this world a better place $[76,77]$. Thus, the home confinement caused by COVID-19, with universities closed, and all teaching becoming virtual, tested the sustainability of the education system. Thus, higher education institutions must ensure inclusive, equitable, and quality education that reduces the digital divide while promoting sustainable activities [78,79]. In addition, according to [80,81], there are significant opportunities to learn from the pedagogical developments of other universities in order to strengthen our collective response to COVID-19 now and into the future. Furthermore, COVID-19 had adverse effects on the well-being of students in four countries - Cambodia, Nigeria, Oman, and Spain — which led us to understand the crosscultural impacts of COVID-19 on higher education students [82]. Based on these results, we conclude that COVID-19 confinement changed students' learning strategies into a more continuous habit, improving their efficiency. For these reasons, better scores in students ${ }^{\prime}$ assessments are expected due to COVID-19 confinement which can be explained by an improvement in their learning performance. This is consistent with previous studies $[83,84]$. The following are four implications drawn from this study's findings:

- To use an MOOC system for learning during the COVID-19 pandemic, the system must be able to inspire students to use the system and to influence their success in higher education.

- Lecturers and mentors help students by listening to their questions and sharing their information with ease, which will enhance student learning collaboration and develop researchers' study skills by using MOOCs during the COVID-19 pandemic.

- Rather than requiring students to use MOOCs during the COVID-19 pandemic, universities should allow them to enroll in classes that teach them how to do so.

- Technology and resources are major concerns in students' ASE when it comes to using MOOCs during COVID-19 pandemic.

\section{Conclusion and Future Work}

This finding showed the validity of the IDT and TAM in the educational context, as well as a deeper understanding of students' possible views of MOOC systems for ASE, LE, and LP during the COVID-19 pandemic. As a result, combining IDT and TAM models in an hypothesis could have significantly better outcomes, and both findings were approved. This research's contribution to MOOC acceptance analysis was discussed. While the TAM's benefits were identified, the findings of this study provided clearer understandings of users' adoption and acceptance of MOOC systems during the COVID-19 pandemic. Similarly, the results suggested that MOOC system developers and programmers carefully examine students' needs and ensure that the chosen solutions successfully meet those demands. The model used in this study measured eight revolutionary aspects of MOOC systems that may be important factors in students' acceptance during the COVID-19 pandemic. Given these discrepancies, further study is needed to examine the relationship between perceived engagement and perceived compatibility of using MOOCs system usability during COVID-19 pandemic. While this study produced remarkable results, it did have certain limitations, one of which was that the sample size of the study was limited to one university. As a result, the findings do not reflect the success of private colleges or teachers in public schools. Furthermore, the study contains no qualitative evidence, because it is based on students' expectations, which could vary from teachers' perceptions. Future 
studies should replicate the research in different countries with different values in order to better examine these other limitations.

Funding: This work was supported through the Annual Funding track by the Deanship of Scientific Research, Vice Presidency for Graduate Studies and Scientific Research, King Faisal University, Saudi Arabia [Project No. AN000526].

Institutional Review Board Statement: This study was conducted according to the guidelines of the Declaration of Helsinki, and approved by the Research Ethics Committee at King Faisal University. Approval code is KFU-REC-2021-DEC-EA000311 and Approval Date is 1 December 2021.

Informed Consent Statement: Informed consent was obtained from all subjects involved in the study.

Data Availability Statement: Not applicable.

Conflicts of Interest: The author declare no conflict of interest.

$\begin{array}{ll}\text { Abbreviations } \\ \text { MOOCs } & \begin{array}{l}\text { massive open online courses } \\ \text { observability } \\ \text { OB }\end{array} \\ \text { CO } & \begin{array}{l}\text { complexity } \\ \text { trialability }\end{array} \\ \text { TR } & \text { perceived usefulness } \\ \text { PU } & \text { perceived ease-of-use } \\ \text { PEU } & \text { innovation diffusion theory } \\ \text { IDT } & \text { technology acceptance model } \\ \text { TAM } & \text { academic self-efficacy } \\ \text { ASE } & \text { learning engagement } \\ \text { LE } & \text { learning persistence } \\ \text { LP } & \text { Statistical Package for the Social Sciences } \\ \text { SPSS } & \text { Structural Equation Modeling } \\ \text { SEM } & \text { coronavirus disease 2019 } \\ \text { COVID-19 } & \text { average variance extracted } \\ \text { AVE } & \text { inter-construct correlations } \\ \text { IC } & \text { confirmatory factor analysis } \\ \text { CFA } & \end{array}$

\section{References}

1. Veletsianos, G.; Collier, A.; Schneider, E. Digging deeper into learners' experiences in MOOCs: Participation in social networks outside of MOOCs, notetaking and contexts surrounding content consumption. Br. J. Educ. Technol. 2015, 46, 570-587. [CrossRef]

2. McAuley, A.; Stewart, B.; Siemens, G.; Cormier, D. The MOOC Model for Digital Practice. 2010. Available online: https: / / oerknowledgecloud.org/sites/oerknowledgecloud.org/files/MOOC_Final.pdf (accessed on 17 August 2021).

3. Barclay, C.; Logan, D. Towards an Understanding of the Implementation \& Adoption of Massive Online Open Courses (MOOCs) in a Developing Behaviour \& Information Technology 15 Economy Context. In Proceedings of the Annual Workshop of the AIS Special Interest Group for ICT in Global Development, Vorarlberg, Austria, 1-14 December 2013.

4. Kennedy, J. Characteristics of Massive Open Online Courses (MOOCs): A Research Review, 2009-2012. J. Interact. Online Learn. 2014, 13, 1-15.

5. Zhu, M.; Bonk, C.J.; Doo, M.Y. Self-directed learning in MOOCs: Exploring the relationships among motivation, self-monitoring, and self-management. Educ. Technol. Res. Dev. 2020, 68, 2073-2093. [CrossRef]

6. Shah, D. Year of MOOC-Based Degrees: A Review of MOOC Stats and Trends in 2018. Class Central. 2018. Available online: https:/ / www.classcentral.com/report/moocs-stats-and-trends-2018/ (accessed on 8 September 2021).

7. Che, X.; Luo, S.; Wang, C.; Meinel, C. An attempt at MOOC localization for Chinese-speaking users. Int. J. Inf. Educ. Technol. 2016, 6, 90-96. [CrossRef]

8. Gameel, B.; Wilkins, K. When it comes to MOOCs, where you are from makes a difference. Comput. Educ. 2019, 136, 49-60. [CrossRef]

9. Subramaniam, T.; Suhaimi, N.; Latif, A.; Abu Kassim, Z.; Fadzil, M. MOOCs Readiness: The Scenario in Malaysia. Int. Rev. Res. Open Distance Learn. 2019, 20, 80-101. [CrossRef]

10. Xiong, Y.; Li, H.; Kornhaber, M.L.; Suen, H.K.; Pursel, B.; Goins, D.D. Examining the relations among student motivation, engagement, and retention in a MOOC: A structural equation modeling approach. Glob. Educ. Rev. 2015, 2, $23-33$. 
11. Hew, K.F.; Cheung, W.S. Students' and instructors' use of massive open online courses (MOOCs): Motivations and challenges. Educ. Res. Rev. 2014, 12, 45-58. [CrossRef]

12. Firmin, R.; Schiorring, E.; Whitmer, J.; Willett, T.; Collins, E.D.; Sujitparapitaya, S. Case study: Using MOOCs for conventional college coursework. Distance Educ. 2014, 12, 94-115. [CrossRef]

13. Chen, L.D.; Gillenson, M.L.; Sherrell, D.L. Enticing online consumers: An extended technology acceptance perspective. Inf. Manag. 2002, 39, 705-719. [CrossRef]

14. Chen, X.; Tao, D.; Zhou, Z. Factors affecting reposting behaviour using a mobile phone-based user-generatedcontent online community application among Chinese young adults. Behav. Inf. Technol. 2019, 38, 120-131. [CrossRef]

15. Tao, D.; Yuan, J.; Shao, F.; Li, D.; Zhou, Q.; Qu, X. Factors affecting consumer acceptance of an online health information portal among young internet users. CIN Comput. Inform. Nurs. 2018, 36, 530-539. [CrossRef] [PubMed]

16. Ullah, N.; Mugahed Al-Rahmi, W.; Alzahrani, A.I.; Alfarraj, O.; Alblehai, F.M. Blockchain Technology Adoption in Smart Learning Environments. Sustainability 2021, 13, 1801. [CrossRef]

17. Abuhassna, H.; Al-Rahmi, W.M.; Yahya, N.; Zakaria, M.A.Z.M.; Kosnin, A.B.M.; Darwish, M. Development of a new model on utilizing online learning platforms to improve students' academic achievements and satisfaction. Int. J. Educ. Technol. High. Educ. 2020, 17, 38. [CrossRef]

18. Alyoussef, I.Y.; Alamri, M.M.; Al-Rahmi, W.M. Social media use (SMU) for teaching and learning in Saudi Arabia. Int. J. Recent Technol. Eng. 2019, 8, 942-946.

19. Al-Rahmi, W.M.; Aldraiweesh, A.; Yahaya, N.; Kamin, Y.B. Massive open online courses (MOOCS): Systematic literature review in Malaysian higher education. Int. J. Eng. Technol. 2018, 7, 2197-2202. [CrossRef]

20. Hsu, J.Y.; Chen, C.C.; Ting, P.F. Understanding MOOC continuance: An empirical examination of social support theory. Interact Learn. Environ. 2018, 26, 1100-1118. [CrossRef]

21. Alalwan, N.; Al-Rahmi, W.M.; Alfarraj, O.; Alzahrani, A.; Yahaya, N.; Al-Rahmi, A.M. Integrated three theories to develop a model of factors affecting students' academic performance in higher education. IEEE Access 2019, 7, 98725-98742. [CrossRef]

22. Ullah, N.; Alnumay, W.S.; Al-Rahmi, W.M.; Alzahrani, A.I.; Al-Samarraie, H. Modeling cost saving and innovativeness for blockchain technology adoption by energy management. Energies 2020, 13, 4783. [CrossRef]

23. Moafa, F.A.; Ahmad, K.; Al-Rahmi, W.M.; Yahaya, N.; Kamin, Y.B.; Alamri, M.M. Develop a model to measure the ethical effects of students through social media use. IEEE Access 2018, 6, 56685-56699. [CrossRef]

24. Fianu, E.; Blewett, C.; Ampong, G.; Ofori, K. Factors affecting MOOC usage by students in selected Ghanaian universities. Educ. Sci. 2018, 8, 70. [CrossRef]

25. Wu, J.H.; Wang, S.C. What drives mobile commerce? An empirical evaluation of the revised technology acceptance model. Inf. Manag. 2005, 42, 719-729. [CrossRef]

26. Lee, Y.H.; Hsieh, Y.C.; Hsu, C.N. Adding innovation diffusion theory to the technology acceptance model: Supporting employees intentions to use e-learning systems. J. Educ. Technol. Soc. 2011, 14, 124-137.

27. Yadav, R.; Mahara, T. An empirical study of consumers intention to purchase wooden handicraft items online: Using extended technology acceptance model. Glob. Bus. Rev. 2019, 20, 479-497.

28. Alenazy, W.M.; Al-Rahmi, W.M.; Khan, M.S. Validation of TAM model on social media use for collaborative learning to enhance collaborative authoring. IEEE Access 2019, 7, 71550-71562. [CrossRef]

29. Rogers, E.M. Diffusion of Innovations, 4th ed.; Free Press: New York, NY, USA, 1995.

30. Davis, F.; Bagozzi, R.; Warshaw, P. User acceptance of computer technology: A comparison of two theoretical models. Manag. Sci. 1989, 35, 982-1003. [CrossRef]

31. Al-Rahmi, W.M.; Yahaya, N.; Aldraiweesh, A.A.; Alturki, U.; Alamri, M.M.; Saud, M.S.B.; Kamin, Y.B.; Aljeraiwi, A.A.; Alhamed, O.A. Big data adoption and knowledge management sharing: An empirical investigation on their adoption and sustainability as a purpose of education. IEEE Access 2019, 7, 47245-47258. [CrossRef]

32. Tobbin, P.E. Modeling Adoption of Mobile Money Transfer: A Consumer Behaviour Analysis. In Proceedings of the 2nd International Conference on Mobile Communication Technology for Development, Kampala, Uganda, 10-11 November 2010.

33. Lee, Y.H. Exploring Key Factors That Affect Consumers to Adopt E-Reading Services. Master's Thesis, Huafan University, New Taipei City, Taiwan, 2007.

34. Altalhi, M.M. Towards Understanding the Students' Acceptance of MOOCs: A Unified Theory of Acceptance and Use of Technology (UTAUT). Int. J. Emerg. Technol. Learn. 2021, 16, 237-253. [CrossRef]

35. Al-Ammary, J.H.; Al-Sherooqi, A.K.; Al-Sherooqi, H.K. The acceptance of social networking as a learning tools at University of Bahrain. Int. J. Inf. Educ. Technol. 2014, 4, 208-214. [CrossRef]

36. Al-Rahmi, W.M.; Alzahrani, A.I.; Yahaya, N.; Alalwan, N.; Kamin, Y.B. Digital communication: Information and communication technology (ICT) usage for education sustainability. Sustainability 2020, 12, 5052. [CrossRef]

37. Al-Rahmi, W.; Aldraiweesh, A.; Yahaya, N.; Kamin, Y.B.; Zeki, A.M. Massive open online courses (MOOCs): Data on higher education. Data Brief 2019, 22, 118-125. [CrossRef] [PubMed]

38. Bandura, A. Self-efficacy: Toward a unifying theory of behavioral change. Psychol. Rev. 1977, 84, 191-215. [CrossRef]

39. You, J.W. The relationship among academic procrastination, self-regulated learning, fear, academic self-efficacy, and perceived academic control in e-Learning. J. Korean Assoc. Educ. Inf. Media 2012, 18, 249-271.

40. Milligan, C.; Littlejohn, A.; Margaryan, A. Patterns of engagement in connectivist MOOCs. J. Online Learn. Teach. 2013, 9, 149-159. 
41. You, J.W.; Song, Y.H. Probing the interaction effects of task value and academic self-efficacy on learning engagement and persistence in an e-learning Course. Korean J. Leaner Cent. Curric. Instr. 2013, 13, 91-112.

42. Puzziferro, M. Online technologies self-efficacy and self-regulated learning as predictors of final grade and satisfaction in college-level online courses. Am. J. Distance Educ. 2008, 22, 72-89. [CrossRef]

43. Wang, Y.; Baker, R. Content or platform: Why do students complete MOOCs? J. Online Learn. Teach. 2015, 11, 17.

44. Breslow, L.; Pritchard, D.E.; DeBoer, J.; Stump, G.S.; Ho, A.D.; Seaton, D.T. Studying learning in the worldwide classroom: Research into edX's first MOOC. Res. Pract. Assess. 2013, 8, 13-25.

45. Coates, H. Student Engagement in Campus-Based and Online Education; University Connections; Routledge: London, UK, 2006.

46. Fredricks, J.A.; Blumenfeld, P.C.; Paris, A.H. School engagement: Potential of the concept, state of the evidence. Rev. Educ. Res. 2004, 74, 59-109. [CrossRef]

47. He, Y.C. Self-Determination among Adult Chinese English Language Learners: The Relationship among Perceived Autonomy Support, Intrinsic Motivation, and Engagement. Ph.D. Thesis, University of Southern California, Los Angeles, CA, USA, 2009.

48. Ramesh, A.; Goldwasser, D.; Huang, B.; Daumé, H., III; Getoor, L. Modeling learner engagement in MOOCs using probabilistic soft logic. NIPS Workshop Data Driven Educ. 2013, 21, 62.

49. Joo, Y.; Kim, N.; Kim, G. The Structural relationship among self-efficacy, internal locus of control, school support, learning flow, satisfaction and learning persistence in cyber education. Korean J. Educ. Technol. 2010, 26, 25-55. [CrossRef]

50. Shin, N. Transactional presence as critical predictors of success in distance learning. Distance Educ. 2003, 24, 48-58. [CrossRef]

51. Reich, J.; Emanuel, J.; Nesterko, S.O.; Seaton, D.T.; Mullaney, T.; Waldo, J.; Chuang, I.; Ho, A. HeroesX: The Ancient Greek Hero: Spring 2013 Course Report. 2014. Available online: https:/ / papers.ssrn.com/sol3/papers.cfm?abstract_id=2382246 (accessed on 1 June 2021).

52. Impey, C.D.; Wenger, M.C.; Austin, C.L. Astronomy for astronomical numbers: A worldwide massive open online class. Int. Rev. Res. Open Distrib. Learn. 2015, 16, 57-79. [CrossRef]

53. Hair, J.F.; Sarstedt, M.; Ringle, C.M.; Mena, J.A. An assessment of the use of partial least squares structural equation modeling in marketing research. J. Acad. Mark. Sci. 2012, 40, 414-433. [CrossRef]

54. Park, Y.; Chen, J.V. Acceptance and adoption of the innovative use of smartphone. Ind. Manag. Data Syst. 2007, 107, 1349-1365. [CrossRef]

55. Giovanis, A.N.; Binioris, S.; Polychronopoulos, G. An extension of TAMmodel with IDT and security/privacy risk in the adoption of internet banking services in Greece. EuroMed J. Bus. 2012, 7, 24-53. [CrossRef]

56. Shih, T.-Y. Key factors of marketing strategies of mobile service innovations. Int. J. Innov. Learn. 2014, 16, 448-466. [CrossRef]

57. Pintrich, P.R.; De Groot, E.V. Motivational and self-regulated learning components of classroom academic performance. J. Educ. Psychol. 1990, 82, 33-40. [CrossRef]

58. Sun, J.C.Y.; Rueda, R. Situational interest, computer self-efficacy and self-regulation: Their impact on student engagement in distance education. Br. J. Educ. Technol. 2012, 43, 191-204. [CrossRef]

59. Alamri, M.M.; Almaiah, M.A.; Al-Rahmi, W.M. Social media applications affecting Students' academic performance: A model developed for sustainability in higher education. Sustainability 2020, 12, 6471. [CrossRef]

60. Chow, Y.S.; Teicher, H. Probability Theory: Independence, Interchangeability, Martingales; Springer Science \& Business Media: Berlin, Germany, 2012.

61. Fornell, C.; Larcker, D.F. Evaluating structural equation models with unobservable variables and measurement error. J. Mark. Res. 1981, 18, 39-50. [CrossRef]

62. Alamri, M.M.; Almaiah, M.A.; Al-Rahmi, W.M. The Role of Compatibility and Task-Technology Fit (TTF): On Social Networking Applications (SNAs) Usage as Sustainability in Higher Education. IEEE Access 2020, 8, 161668-161681. [CrossRef]

63. Al-Adwan, A.S. Investigating the drivers and barriers to MOOCs adoption: The perspective of TAM. Educ. Inf. Technol. 2020, 25, 5771-5795. [CrossRef]

64. Arpaci, I.; Al-Emran, M.; Al-Sharafi, M.A. The impact of knowledge management practices on the acceptance of Massive Open Online Courses (MOOCs) by engineering students: A cross-cultural comparison. Telemat. Inform. 2020, 54, 101468. [CrossRef]

65. Venkatesh, V.; Morris, M.G.; Davis, G.B.; Davis, F.D. User acceptance of information technology: Toward a unified view. MIS Q. 2003, 27, 425-478. [CrossRef]

66. Virani, S.R.; Saini, J.R.; Sharma, S. Adoption of massive open online courses (MOOCs) for blended learning: The Indian educators perspective. Interact. Learn. Environ. 2020, 4, 1-17. [CrossRef]

67. Ing, H.C.; Yahaya, N.; Kumar, L.; Al-Rahmi, W.M. Examining Learners' Interaction Pattern in Asynchronous Text-Based Online Learning. I-Manag. J. Educ. Technol. 2020, 16, 9.

68. Almaiah, M.A.; Alamri, M.M.; Al-Rahmi, W.M. Analysis the effect of different factors on the development of Mobile learning applications at different stages of usage. IEEE Access 2019, 8, 16139-16154. [CrossRef]

69. Pozón-López, I.; Higueras-Castillo, E.; Muñoz-Leiva, F.; Liébana-Cabanillas, F.J. Perceived user satisfaction and intention to use massive open online courses (MOOCs). J. Comput. High. Educ. 2021, 33, 85-120. [CrossRef]

70. Yuen, K.F.; Cai, L.; Qi, G.; Wang, X. Factors influencing autonomous vehicle adoption: An application of the technology acceptance model and innovation diffusion theory. Technol. Anal. Strateg. Manag. 2020, 33, 505-519. [CrossRef] 
71. Al-Maatouk, Q.; Othman, M.S.; Aldraiweesh, A.; Alturki, U.; Al-Rahmi, W.M.; Aljeraiwi, A.A. Task-technology fit and technology acceptance model application to structure and evaluate the adoption of social media in academia. IEEE Access 2020, 8, 78427-78440. [CrossRef]

72. Al-Rahmi, W.M.; Othman, M.S.; Yusuf, L.M. Effect of engagement and collaborative learning on satisfaction through the use of social media on Malaysian higher education. Research Journal of Applied Sciences. Eng. Technol. 2015, 9, 1132-1142.

73. Widianto, M.H. Analysis of Application of Online Work Exchange Using Technology Acceptance Model and Innovation Diffusion Theory. J. Theor. Appl. Inf. Technol. 2020, 98, 1697-1711.

74. Jung, Y.; Lee, J. Learning engagement and persistence in massive open online courses (MOOCS). Comput. Educ. 2018, 122, 9-22. [CrossRef]

75. Liu, Y.; Li, H. Mobile internet diffusion in China: An empirical study. Ind. Manag. Data Syst. 2010, 110, 309-324. [CrossRef]

76. Wolff, L.A. Sustainability education in risks and crises: Lessons from COVID-19. Sustainability 2020, 12, 5205. [CrossRef]

77. Al-Rahmi, A.M.; Shamsuddin, A.; Alturki, U.; Aldraiweesh, A.; Yusof, F.M.; Al-Rahmi, W.M.; Aljeraiwi, A.A. The influence of information system success and technology acceptance model on social media factors in education. Sustainability 2021, 13, 7770. [CrossRef]

78. Faura-Martínez, U.; Lafuente-Lechuga, M.; Cifuentes-Faura, J. Sustainability of the Spanish university system during the pandemic caused by COVID-19. Educ. Rev. 2021, 2, 1-19. [CrossRef]

79. Al-Rahmi, W.M.; Alkhalaf, S. An empirical investigation of adoption Big Data in higher education sustainability. Entrep. Sustain. Issues 2021, 9, 108. [CrossRef]

80. Crawford, J.; Butler-Henderson, K.; Rudolph, J.; Malkawi, B.; Glowatz, M.; Burton, R.; Magni, P.; Lam, S. COVID-19: 20 countries higher education intra-period digital pedagogy responses. J. Appl. Learn. Teach. 2020, 3, 1-20.

81. Al-Rahmi, A.M.; Al-Rahmi, W.M.; Alturki, U.; Aldraiweesh, A.; Almutairy, S.; Al-Adwan, A.S. Exploring the factors affecting mobile learning for sustainability in higher education. Sustainability 2021, 13, 7893. [CrossRef]

82. Cifuentes-Faura, J.; Obor, D.O.; To, L.; Al-Naabi, I. Cross-cultural impacts of COVID-19 on higher education learning and teaching practices in Spain, Oman, Nigeria and Cambodia: A cross-cultural study. J. Univ. Teach. Learn. Pract. 2021, 18, 8. [CrossRef]

83. Gonzalez, T.; De La Rubia, M.A.; Hincz, K.P.; Comas-Lopez, M.; Subirats, L.; Fort, S.; Sacha, G.M. Influence of COVID-19 confinement on students' performance in higher education. PLoS ONE 2020, 15, e0239490. [CrossRef] [PubMed]

84. Sayaf, A.M.; Alamri, M.M.; Alqahtani, M.A.; Al-Rahmi, W.M. Information and Communications Technology Used in Higher Education: An Empirical Study on Digital Learning as Sustainability. Sustainability 2021, 13, 7074. [CrossRef] 